\title{
Funkcjonowanie szaty roślinnej w warunkach miejskich The functioning of plant cover in urban conditions
}

\author{
Czesław Wysocki \\ Szkoła Główna Gospodarstwa Wiejskiego \\ Wydział Ogrodnictwa, Biotechnologii i Architektury Krajobrazu \\ ul. Nowoursynowska 159, 02-776 Warszawa \\ czeslaw.wysocki@gmail.com
}

Zarys treści. Rozpoznanie funkcjonowania szaty roślinnej na obszarach zurbanizowanych jest ważnym zagadnieniem w kontekście poprawy warunków życia ich mieszkańców. W miastach specyficzne warunki klimatyczne, glebowe, wodne, związane z działalnością człowieka, wywierają znaczny wpływ na występującą tam roślinność. Przejawia się to między innymi w mniejszej jej produktywności i w skróceniu okresu wegetacji, w porównaniu do terenów pozamiejskich. Ponadto w miastach mamy do czynienia z intensywnym procesem synantropizacji. W wyniku tego procesu pojawiają się zbiorowiska roślinne, w których gatunki są często obcego pochodzenia. Przystosowują się one stosunkowo łatwo do specyficznych warunków siedliskowych. Nie wymagają prawie żadnych zabiegów pielęgnacyjnych. W związku z powyższym należałoby rozważyć możliwość wykorzystania ich w miastach, szczególnie na obszarach ekstensywnie użytkowanych.

Słowa kluczowe: miasto, roślinność i rośliny, warunki siedliskowe i biotyczne, synantropizacja.

\section{Wstęp}

Problem właściwego funkcjonowania szaty roślinnej w warunkach zurbanizowanych jest niezwykle ważny w kontekście poprawy warunków życia mieszkańców miast. Obecnie w miastach na kuli ziemskiej żyje ponad połowa jej mieszkańców, a w Polsce około 60\% (GUS, 2017). W związku z tym pilnym zadaniem staje się zapewnienie mieszkańcom miast właściwych warunków do życia, m.in. poprzez odpowiednie kształtowanie terenów wypoczynkowych. W wielu krajach Unii Europejskiej tereny wypoczynkowe stają się równie ważnym komponentem miasta jak zabudowa mieszkaniowa. Obecnie nowym trendem w realizacji terenów wypoczynkowych jest wykorzystywanie i utrzymywanie terenów niezagospodarowanych, terenów poprzemysłowych i innych obszarów, które w mniejszym lub większym stopniu można przystosować do funkcji rekreacyjnej (Maksymiuk, 2008). Ponadto na tych terenach ogranicza się stosowanie intensywnych zabiegów pielęgnacyjnych. Wiąże się to z proekologicznym trendem, z jakim mamy do czynienia w Unii Europejskiej w zakresie akceptacji „naturalnego krajobrazu” (Kühn N., 2006; Sikorski, 2013; Rink i inni, 2018; Mc Kinney i inni, 2018).

Jak wiadomo, środowisko przyrodnicze miast jest silnie przekształcone przez człowieka. Szczególnie dotyczy to roślinności, która stanowi jeden z ważniejszych elementów struktury przestrzennej prawie każdego miasta. Pełni ona wiele funkcji, stwarzając miesz- 
kańcom lepsze warunki do życia w ramach tzw. usług ekosystemowych (Szumacher, 2011; Sudra, 2015; Sikorska i inni, 2016). W związku z powyższym rozpoznanie zagrożeń, które wpływają na wzrost i rozwój roślinności, jest niezwykle zasadne.

Celem niniejszego opracowania jest przedstawienie problemu funkcjonowania roślinności zarówno świadomie kształtowanej przez człowieka, jak również pojawiającej się spontanicznie w specyficznych warunkach środowiska zurbanizowanego.

\section{Koncepcja i zakres pracy}

Praca ma charakter przeglądowy. Do jej realizacji wykorzystano zarówno piśmiennictwo z przedmiotowego zakresu, jak również wyniki badań własnych. Zakres pracy obejmuje charakterystykę abiotycznych warunków środowiska przyrodniczego miast wraz z ich wpływem na funkcjonowanie roślinności, niezależnie od jej rodzaju i pochodzenia oraz wskazania do wykorzystania roślinności spontanicznej w procesie kształtowania struktury przyrodniczej miast. Piśmiennictwo w tym zakresie jest bogate, a szczególne zasługi na tym polu mają nie tylko jednostki badawcze na świecie (Devigneaud i Denayer-De Smet, 1977; Sukopp, 1983), ale również i w Polsce. Już w latach siedemdziesiątych oraz osiemdziesiątych XX w. wykonywały one intensywne, kompleksowe badania w tym kierunku. Prace badawcze prowadziło wiele uczelni i innych jednostek badawczych, szczególnie na obszarze Warszawy, Krakowa oraz Łodzi, a ich efektem było wydanie pokaźnych rozmiarów monografii choćby pod redakcją Zimnego (1983, 1990), Szczepanowskiej (1984), Krawczyka i Węcławowicza (2001) i wielu innych, które obejmowały wyniki badań zarówno środowiska abiotycznego, jak i biotycznego obszarów zurbanizowanych. W zakresie badań nad roślinnością miast w Polsce najbardziej wartościowymi w ostatnich latach są publikacje: J. Chojnackiego (1991), B. Sudnik-Wójcikowskiej (1998), B. Jackowiaka (1998), A. Kozłowskiej (2001), dane zawarte w Opracowaniu ekofizjograficznym do studium uwarunkowań i kierunków zagospodarowania przestrzennego m. st. Warszawy (2006), publikacje P. Sikorskiego (2013), E. Trzaskowskiej (2013), P. Sikorskiego i innych (2015) oraz zamieszczone w Atlasie ekofizjograficznym m. st. Warszawy (2018).

\section{Charakterystyka środowiska przyrodniczego terenów zurbanizowanych}

Z ekologicznego punktu widzenia miasto można traktować jako specyficzne środowisko przyrodnicze, które jest przekształcone na skutek ograniczenia czynnika przyrodniczego na korzyść elementów technicznych (Zimny, 1976; Rebele, 1994). W układzie tym najłatwiej ulegają zmianom takie komponenty środowiska przyrodniczego, jak roślinność, zwierzęta, gleby, a następnie woda, powietrze atmosferyczne i klimat.

Środowisko miejskie cechują nasilające się procesy kseryzacji warunków klimatycznych, toksykacji atmosfery, wody, gleby i organizmów żywych. (Czarnowska i Gworek, 1991; Czerwiński i Pracz, 1990; Sukopp i Wurzel, 1995; Szulczewska, 2002). Zmieniają się na niekorzyść proporcje pomiędzy abiotycznymi składnikami środowiska (zabudowa, infrastruktura drogowa), a biotycznymi (populacje: ludzka, roślin i zwierząt).

Środowisko miejskie charakteryzuje wiele procesów (Zimny, 2005). Jednym z nich jest zmniejszanie się przestrzeni przyrodniczej, polegające głównie na zabudowie obszarów, 
w tym zabudowie infrastrukturą (Li i inni, 2013). Ponadto w warunkach zurbanizowanych występuje zanieczyszczeń gleb, powietrza, wody oraz organizmów żywych, pochodzących głównie z emisji zakładów przemysłowych oraz z ruchu komunikacyjnego (Guo i inni, 2015; Atlas ekofizjograficzny..., 2018).

Działalność człowieka w obrębie obszarów zurbanizowanych prowadzi do znacznych deformacji gleb. Gleby miejskie charakteryzują się: zniekształceniem profilu glebowego, podwyższeniem odczynu glebowego, zasoleniem i skażeniem metalami ciężkimi, szczególnie na obszarach zieleni przyulicznej (Czarnowska i Konecka-Betley, 1984; Biernacka i Madany, 1990; Czarnowska i Gworek, 1991; Blume, 1998; Manta i inni, 2003; Park i inni, 2010). Skala powyższych deformacji gleb uzależniona jest dodatkowo od stopnia antropizacji i wzrasta od terenów otaczających miasto w kierunku jego centralnej części. Ponadto, ze względu na prowadzone w związku z urbanizacją roboty inżynierskie, następuje wyraźne zachwianie stosunków wodnych w glebach, cechujące się znacznie obniżonym poziomem wód gruntowych (Czarnocka i Konecka-Betley, 1984; Czerwiński i Pracz, 1990; Blume, 1998). Dodatkowo występuje wzrost odpływu powierzchniowego wód i związane z nim spadki intensywności infiltracji (Stańczyk, 2015).

W porównaniu do obszarów pozamiejskich warunki klimatyczne miast cechują się przede wszystkim wyższą temperaturą powietrza: o $0,5-1,5^{\circ} \mathrm{C}$ w przypadku średniej rocznej i aż o $2-6^{\circ} \mathrm{C}$ w dni słoneczne, tworząc tzw. wyspę ciepła (Horbert, 1978; Landsberg, 1981; Oke, 1982; Böhm, 1998; Kozłowska-Szczęsna i inni, 2001; Weng i inni, 2004; Błażejczyk i inni, 2014). Konsekwencją tego stanu jest mniejsza wilgotność powietrza, zarówno w okresie zimowym, jak i letnim. Zmniejszone jest również promieniowanie słoneczne docierające do środowiska miejskiego w stosunku do terenów niezurbanizowanych (Godaard i inni, 2009; Błażejczyk i inni, 2014).

Zanieczyszczenia pyłowe i gazowe stanowią czynnik ograniczający wzrost i rozwój roślinności. Zanieczyszczenie pyłowe jest od 2 do 4 razy, a gazowe $\left(\mathrm{NOx}, \mathrm{SO}_{2}, \mathrm{CO}_{2}\right)$ od 5 do 25 razy większe w miastach niż na obszarach pozamiejskich, choć w ostatnim okresie obserwuje się znaczne ich zmniejszenie (Horbert, 1978). Zmieniła się w ostatnich latach również struktura typu zanieczyszczeń. Okazało się, że skażenia przemysłowe w tym energetyka, stanowią coraz mniejsze zagrożenie, natomiast wzrasta poziom zanieczyszczenia spowodowanego transportem samochodowym.

Konsekwencją mechanicznych i chemicznych przekształceń środowiska glebowego są zaburzenia jego aktywności biologicznej. Aktywność biologiczna gleb warunkuje optymalne funkcjonowanie biocenoz, w tym roślinności. Z badań prowadzonych przez D. Żukowską-Wieszczek i innych (1984), J. A. Harrisa (1991) oraz A. Rusakova i V. Novikova (2003) w tym zakresie wynika, że tempo rozkładu materii organicznej w glebach jest zależne od stopnia antropizacji, tj. na obszarach zieleni przyulicznej proces ten jest wyraźnie wolniejszy niż w parkach.

\section{Wpływ warunków środowiska miejskiego na funkcjonowanie roślinności}

Przedstawione wyżej specyficzne warunki środowiska miejskiego wpływają niewątpliwie na całą biocenozę, w tym na roślinność. Konsekwencją tego stanu są zaburzenia w jej rozwoju. Przejawia się to między innymi zmniejszaniem jej produktywności, skróceniem okresu wegetacji oraz synantropizacją występującej w miastach roślinności. 
Produktywność jest ważnym miernikiem funkcjonowania obszarów przyrodniczych. W warunkach zurbanizowanych powinna istnieć równowaga pomiędzy wielkością biomasy produkowanej przez roślinność terenów zieleni, a wypełnianiem przez nią funkcji higieniczno-sanitarnej, tj. zdolnością do wychwytywania zanieczyszczeń pyłowych, gazowych, neutralizowania substancji toksycznych z gleby, wiązaniem w procesie asymilacji dwutlenku węgla, wydzielaniem tlenu czy zwiększaniem wilgotności powietrza oraz łagodzeniem amplitudy temperatury. Z badań prowadzonych $w$ tym zakresie nad trawnikami, które zajmują około $60 \%$ powierzchni terenów zieleni w miastach wynika, że te położone na obszarach przyulicznych charakteryzują się ponad dwukrotnie niższą produktywnością w porównaniu do zlokalizowanych w parkach (Wysocki i Zimny, 1983; Wysocki, 1994) (tab. 1). Trawniki, niezależnie od położenia w mieście, znacznie odbiegają produktywnością od podobnych układów roślinnych występujących w krajobrazach pozamiejskich, np. produkcja biomasy łąki typu świeżego (zespół Arrhenatheretum elatioris) jest znacznie wyższa od produktywności, podobnej pod względem struktury i składu gatunkowego runi trawników parkowych (Jankowska, 1971; Pasternak, 1980).

Innym rodzajem zaburzeń roślinności w warunkach zurbanizowanych jest odnotowane skrócenie ich okresu wegetacji, zwłaszcza na obszarach zieleni przyulicznej (Mędrzycki, 1990, tab. 2). Ponadto ma miejsce wcześniejsze jego rozpoczęcie i szybsze zakończenie (Borowski i Latocha, 2006), a przyczyną takiego stanu jest zapewne wyższa temperatura panująca w miastach. Na podstawie wyników przedstawionych w tabeli 2 można stwierdzić, że drzewa rosnące w parkach cechują się na ogół dłuższym okresem wegetacji niż na terenach przyulicznych. Różnice w długości okresu wegetacji są widoczne zwłaszcza dla dwóch gatunków: jesionu wyniosłego (Fraxinus excelsior) oraz lipy drobnolistnej (Tilia cordata) - dochodzą one nawet do kilkudziesięciu dni. Ponadto wśród badanych drzew, niezależnie od miejsca ich występowania, niektóre charakteryzują się znacznie dłuższym

Tabela 1. Produktywność różnych powierzchni trawiastych $\mathrm{w} \mathrm{g} / \mathrm{m}^{2} / \mathrm{rok}$ Productivity of different kinds of grassy sward in $\mathrm{g} / \mathrm{m}^{2} /$ year

\begin{tabular}{|l|l|c|}
\hline Miasto & Trawniki przyuliczne / Street lawns & 163,6 \\
\hline Town & Trawniki parkowe / Park lawns & 374,6 \\
\hline Krajobraz rolniczy & Pastwisko typu świeżego / Lolio-Cynosuretum pasture & 250,3 \\
Agricultural landscape & Łąka typu świeżego / Arrhenatheretum elatioris meadow & 873,8 \\
\hline
\end{tabular}

Źródło/Source: Jankowska (1971); Traczyk i Kochev (1974); Pasternak (1980); Wysocki (1994).

Tabela 2. Długość okresu wegetacji (w dniach) wybranych gatunków drzew w warunkach miejskich na przykładzie Warszawy

Length of the growing season (in days) for selected tree species in urban conditions exemplified by Warsaw

\begin{tabular}{|l|c|c|}
\hline \multicolumn{1}{|c|}{ Gatunek drzewa / Tree species } & Tereny przyuliczne / Street areas & Parki / Parks \\
\hline Klon zwyczajny/Norway maple (Acer platanoides) & $183-223$ & $201-225$ \\
Klon jawor/Sycamore (Acer pseudoplatanus) & $159-193$ & $182-198$ \\
Jesion wyniosły/Ash (Fraxinus excelsior) & $195-225$ & $230-245$ \\
Lipa drobnolistna/Small-leaved lime (Tilia cordata) & $197-215$ & $220-229$ \\
Lipa srebrzysta/Silver lime (Tilia tomentosa) & $217-229$ & $230-235$ \\
\hline
\end{tabular}

Źródło/Source: Mędrzycki (1990). 
okresem wegetacji. Do nich zaliczyć należy m.in. lipę srebrzystą (Tilia tomentosa). Z kolei najkrótszym okresem wegetacji spośród badanych gatunków cechował się klon jawor (Acer pseudoplatanus).

$\mathrm{Na}$ obszarze zieleni miejskiej, oprócz zbioru gatunków posianych lub posadzonych w sposób świadomy, występuje roślinność synantropijna. Pojawia się ona najczęściej na terenach niezagospodarowanych, w procesie sukcesji ekologicznej. Formuje się na siedliskach, które podlegają ustawicznej, najczęściej niezamierzonej ingerencji człowieka (Chojnacki, 1991; Sudnik-Wójcikowska, 1998; Jackowiak, 1998; Faliński, 2001; Mc Kinney, 2002; Sikorski, 2013; Trzaskowska i Miszczuk, 2017).

Z syntaksonomicznego punktu widzenia roślinność spontaniczna obszarów zurbanizowanych jest bardzo zróżnicowana (Janecki, 1983; Chojnacki, 1991; Sudnik-Wójcikowska, 1998; Kozłowska, 2001; Trzaskowska, 2013; Atlas ekofizjograficzny..., 2018). Warto w tym miejscu zaznaczyć, że zbiorowiska te występują w różnych warunkach siedliskowych, niejednokrotnie ekstremalnie trudnych dla ich wzrostu i rozwoju. Stanowią one w tych miejscach często jedyną możliwość utrzymania się szaty roślinnej (Rink i inni, 2018). Wśród tych zbiorowisk, szczególnie ważne dla potrzeb kształtowania zieleni w miastach są takie, które w swoim składzie florystycznym zawierają gatunki wieloletnie. Reprezentowane są przez zespoły roślinne z klasy Artemisietea vulgaris. Do takich należy zaliczyć między innymi zbiorowiska bylicy i wrotycza (Artemisio-Tanacetetum, fot. 1), żmijowca i nostrzyków (Echio-Melitotetum), czy też związane z miejscami wydeptywanymi - murawy dywanowe (Lolio-Polygonetum arenastri). Z kolei na siedliskach uboższych, acidofilnych, wykształcają się kadłubowe murawy piaskowe z klasy Koelerio-Corynephoretea canescentis, zaś na obszarach ciepłolubnych i lekko zasadowych - zbiorowiska zbliżone do muraw kserotermicz-

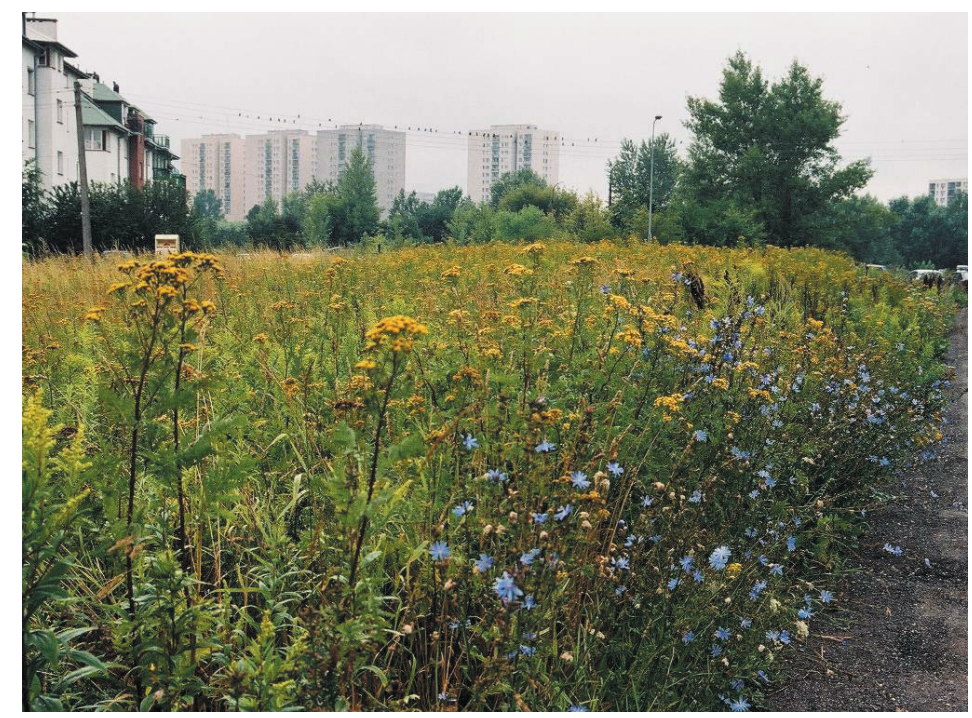

Fot. 1. Przykład występowania roślinności spontanicznej (zespół Artemisio-Tanacetetum) na osiedlu w Warszawie (fot. C. Wysocki)

An example of the occurrence of spontaneous vegetation (of the association Artemisio-Tanacetetum) on one of the housing estates in Warsaw 
nych z klasy Festuco-Brometea (Kozłowska, 2001; Sikorski i inni, 2015). Z punktu widzenia wykorzystania rekreacyjnego nieco mniejszą rolę w miastach odgrywają niezbyt trwałe zbiorowiska ruderalne, z jedno- lub dwuletnimi gatunkami roślin. Najczęściej występują one w miejscach o dużym stopniu antropopresji. Spośród wielu występujących na obszarze miast należy wymienić przede wszystkim zbiorowiska: jęczmienia płonnego (Hordeetum murini), łobody szarej (Atriplicetum tataricae) czy łobody błyszczącej (Atriplicetum nitentis) (Chojnacki, 1991).

Cechą charakterystyczną szaty roślinnej miast, w porównaniu do obszarów niezurbanizowanych, jest znacznie większy udział gatunków synantropijnych we florze roślin naczyniowych (tab. 3). Jak wynika z tabeli 3, rośliny pochodzenia synantropijnego stanowią w przytoczonych miastach ponad 60\% ogólnej liczby gatunków występujących na ich obszarach (Jackowiak, 1998; Sudnik-Wójcikowska, 1998). Natomiast procentowy udział takich gatunków w Puszczy Kampinoskiej czy w Puszczy Białowieskiej, na terenach o większej powierzchni niż porównywane miasta, jest niższy i waha się od 35 do 45\%. Powodem takiego stanu jest przede wszystkim duża zmienność siedlisk oraz niezwykle różnorodna działalność człowieka.

Roślinność obszarów zurbanizowanych cechuje przewaga gatunków obcego pochodzenia, których przystosowanie do specyficznych warunków siedliskowych jest prawdopodobnie większe niż gatunków rodzimych (Zerbe i inni, 2004; Kühn I. i Klotz, 2006). W związku z istniejącą w środowisku miejskim wyspą ciepła obserwuje się pojawienie się flory ciepłolubnej z kręgu roślinności śródziemnomorskiej. Zanikają natomiast gatunki rodzime, szczególnie leśne, muraw kserotermicznych, okrajków, zbiorowisk wodnych, bagiennych i torfowiskowych (Landolt, 1991; Sukopp, 2004).

Wśród gatunków zielnych, które preferują warunki miejskie, wymienić należy m.in. jęczmień płonny (Hordeum murinum), mikołajek płaskolistny (Eryngium planum), stokłosę płonną (Bromus sterilis), łobodę szarą (Atriplex tatarica). Rośliny te, znane pod nazwą urbanofili, w większości pochodzą z cieplejszych regionów Europy Południowej (Wittig, Kunming, 1993; Jackowiak, 1998; Sudnik-Wójcikowska, 1998; Stawicka i inni, 2006). Wymagają one do optymalnego wzrostu i rozwoju zwiększonej ilości światła oraz wyższej temperatury. Ponadto mają mniejsze wymagania wilgotnościowe i znoszą częściowe zasolenie. Wśród nich przeważają rośliny jedno- i dwuletnie o małej wielkości kwiatów i dużej produkcji diaspor. W podobnych warunkach siedliskowych pojawiają się spontanicznie również gatunki o pędach zdrewniałych, do których zaliczyć należy bożodrzew gruczoł-

Tabela 3. Porównanie liczby gatunków synantropijnych na terenach dwóch miast oraz dwóch puszcz Comparison of numbers of synanthropic plant species in two cities and two primaeval forest areas

\begin{tabular}{|l|c|c|c|}
\hline \multicolumn{1}{|c|}{$\begin{array}{c}\text { Obszar badań } \\
\text { Study area }\end{array}$} & $\begin{array}{c}\text { Powierzchnia } \\
\text { Area } \\
\left(\mathrm{km}^{2}\right)\end{array}$ & $\begin{array}{c}\text { Liczba gatunków na- } \\
\text { czyniowych ogółem } \\
\text { Total number of vas- } \\
\text { cular plants species }\end{array}$ & $\begin{array}{c}\text { Liczba gatunków } \\
\text { synantropijnych } \\
\text { Number of synanth- } \\
\text { ropic species }\end{array}$ \\
\hline Poznań & 229 & 1300 & 819 \\
Warszawa & 430 & 1416 & 941 \\
Puszcza Białowieska / Białowieża Forest & 630 & 1017 & 353 \\
Puszcza Kampinoska / Kampinos Forest & 670 & 1001 & 450 \\
\hline
\end{tabular}

Źródło: Jackowiak (1998); Sudnik-Wójcikowska (1998), zmienione; Kozieł (2010).

Source: Jackowiak (1998); Sudnik-Wójcikowska (1998), modified; Kozieł (2010). 
kowaty (Ailanthus altissima) i budleja Davida (Buddleja davidii). Potwierdzają to wyniki badań przeprowadzonych przez B. Sudnik-Wójcikowską (1998), B. Jackowiaka (1998), M. Weber-Siwirską i M. Czekalskiego (2004) w różnych miastach w Polsce, szczególnie w południowej części kraju, jak również przez I. Kowarika (1990) oraz U. Sachsego i innych (1990) na obszarze miast niemieckich.

Drugą ważną grupę gatunków, która występuje na obszarach zurbanizowanych pospolicie, B. Sudnik-Wójcikowska (1998) nazywa mianem „ogólnie miejskich”. Należą do niej gatunki pospolite o szerszym zakresie tolerancji temperatury oraz węższym - wilgotności podłoża. Do tej grupy zaliczyć można m.in. mniszka pospolitego (Taraxacum sect. ruderale), rdesta ptasiego (Polygonum aviculare), koniczynę białą (Trifolium repens), wrotycza pospolitego (Tanacetum vulgare), krwawnika pospolitego (Achillea millefolium) czy powoja polnego (Convolvulus arvensis). Gatunki te, w zależności od intensywności użytkowania, tworzą w miastach ekstensywne zadarnienia. W stosunku do poprzedniej, ciepłolubnej grupy gatunków grupa ta cechuje się większym udziałem gatunków rodzimych, a obce występują w niej nieco rzadziej. Podobne wyniki badań na powierzchniach trawiastych na obszarze Warszawy otrzymali w swojej pracy C. Wysocki (1994) oraz J. Stawicka i inni (2006). W większości są to gatunki kosmopolityczne, o przewadze rozsiewanych przez wiatr. Mają dużą odporność na uszkodzenia mechaniczne oraz stosunkowo dobrze znoszą zasolenie.

Bardzo ważnymi, z punktu widzenia potrzeb terenów zieleni, są mannica odstająca (Puccinellia distans) oraz łoboda szara (Atriplex tatarica), które pojawiają się w drodze sukcesji roślinnej, szczególnie na terenach podlegających stałemu zasoleniu bądź zanieczyszczeniu związkami ropopochodnymi, tj. w pasie trawnika bezpośrednio przy jezdniach (Jackowiak, 1996; Sudnik-Wójcikowska, 1998; Sukopp, 2004; Stawicka i inni, 2006).

Wartym odnotowania zjawiskiem w kształtowaniu się flory w mieście jest pojawienie się nowych gatunków obcych, o dużej sile dyspersji, które szczególnie rozpowszechniły się w miastach w drugiej połowie XX w. W tej grupie roślin należy wymienić zarówno gatunki o pędach zdrewniałych, jak i zielnych. Gatunki drzewiaste, powiększające swój obszar występowania w miastach, to klon jesionolistny (Acer negundo), robinia akacjowa (Robinia pseudoacacia) czy wspomniany wcześniej bożodrzew gruczołkowaty (Ailanthus altissima). Znajdują one w miastach szczególne warunki dla swego wzrostu i rozwoju (Sachse i inni, 1990; Bornkamm, 2007). Obserwowana jest również ekspansja wielu gatunków zielnych, m.in. rdesta ostrokończystego (Reynoutria japonica), pnącz kolczurki klapowanej (Echinocystis lobata), rozpowszechnionej w Polsce po 1970 r. Ponadto powiększa swój areał w miastach nawłoć późna (Solidago gigantea), czy też spotykany w miejscach zacienionych, na stosunkowo żyznych siedliskach, niecierpek drobnokwiatowy (Impatiens parviflora).

Powyższe gatunki są zaliczane do gatunków inwazyjnych, a więc tych, które zagrażają wzrostowi i rozwojowi roślin rodzimych, stąd ich udział przestrzenny w zieleni miejskiej winien być kontrolowany (Tokarska-Guzik i inni, 2014; Generalna Dyrekcja Ochrony Środowiska, 2014). 


\section{Wykorzystanie roślinności spontanicznej w kształtowaniu środowiska przyrodniczego miast}

Roślinność miasta to nie tylko zieleń urządzona. Obszary zieleni urządzonej, często składającej się z gatunków obcego pochodzenia, ograniczone są głównie do pielęgnowanych terenów miejskich (Kozłowska, 2001). Na pozostałym obszarze ważną rolę odgrywa roślinność powstała w sposób spontaniczny, przy większym lub mniejszym współudziale roślinności półnaturalnej, naturalnej oraz synantropijnej, występująca w miejscach związanych z obecnością człowieka, jak i na terenach zaniedbanych, pozbawionych wszelkiego użytkowania. Pełni ona ważną rolę w funkcjonowaniu całych biocenoz, zwłaszcza w utrzymaniu wielu gatunków zwierząt, dając im schronienie i miejsce żerowania.

W ostatnim czasie idea naturyzacji szaty roślinnej w miastach, a więc akceptacja i wykorzystanie roślinności spontanicznej, jest bardzo silnie propagowana w planowaniu terenów zieleni (Lundholm i Marlin, 2006; Zachariasz, 2012). Według H. Nagendra i D. Gopala (2011) oraz P. G. Angolda i innych (2006) spontaniczna roślinność spełnia lepiej swoje funkcje niż sztuczne nasadzenia roślin, a przy tym także wpływa na większą różnorodność gatunkową. Przykładów wykorzystania roślinności spontanicznej w planowaniu terenów zieleni jest wiele: dawne tereny pokopalniane i poprzemysłowe Nordsternpark w Gelsenkirchen, Landschaftspark Duisburg-Nord w Duisburgu, Gas Works Park w Seattle, stare koszary wojskowe Bornstedter Feld Park w Poczdamie, porzucone dzielnice mieszkaniowe Mile End w Londynie, dawne tory kolejowe High Line Park w Nowym Jorku czy Park im. Romana Kozłowskiego w Warszawie (Zachariasz, 2012). Są to przykłady obiektów architektury krajobrazu, na których zbiorowiska spontaniczne wykształciły się bądź wskutek zachodzącej wtórnej sukcesji roślinnej i zostały zaadaptowane dla potrzeb mieszkańców, bądź też zostały świadomie urządzone przez człowieka. Według P. Sikorskiego (2013) tereny takie spełniają równie dobrze funkcje rekreacyjne jak kosztowne, zakładane od podstaw parki.

Jednym z ważnych problemów ograniczających możliwość wykorzystania roślinności spontanicznej, a w szczególności gatunków synantropijnych, w kształtowaniu krajobrazu przyrodniczego miast, jest stosunek człowieka do ich występowania. Przeważnie rośliny synantropijne, zwane pospolicie chwastami, traktowane są przez ludzi jako coś niepożądanego, coś niewłaściwego, co nie mieści się w przeciętnych standardach estetycznych. Potwierdzeniem tego są wstępne wyniki badań prezentowanych przez B. Szulczewską i innych (2015). Wynika z nich, że mieszkańcy badanych 18 osiedli warszawskich preferują raczej zieleń urządzoną i zadbaną, z większym udziałem odmian roślin i form ogrodowych. Nieco inaczej postrzegają udział roślinności spontanicznej w miastach mieszkańcy krajów bardziej rozwiniętych niż Polska, wskazując na jej pozytywne dla środowiska walory, poprzez podobieństwo do tzw. dzikiej przyrody (Breuste, 2004; White i inni, 2013). Mając to na uwadze, jak i wyjątkową zdolność wzrostu i rozwoju tej grupy roślinności w warunkach miejskich, należy rozważyć wykorzystanie jej w procesie kształtowania terenów zieleni w większym stopniu niż to ma miejsce obecnie (Wysocki i Stawicka, 2000; Kozłowska, 2001; Kühn N., 2006; Goddard i inni, 2009; Trzaskowska, 2011), oczywiście z ograniczeniem stosowania gatunków inwazyjnych. Szczególnie powinno to dotyczyć obszarów, które z różnych powodów nie są lub nie mogą być świadomie zagospodarowane (Sikorski, 2013; Rink i inni, 2018; Mc Kinney i inni, 2018). 


\section{Podsumowanie}

W podsumowaniu niniejszej pracy należy stwierdzić, że w miastach panują niekorzystne warunki dla wzrostu i rozwoju roślin, które w decydujący sposób wpływają na ich funkcjonowanie. Warunki te ograniczają wyraźnie produktywność i wpływają na skrócenie okresu wegetacji niektórych drzew. Na terenach ekstensywnie użytkowanych wykształcają się zbiorowiska spontaniczne o różnym stopniu rozwoju, często też o wyraźnym ciepłolubnym charakterze. Miasta są obszarami, na których kształtuje się specyficzna struktura przestrzenna flory i roślinności. Związane jest to przede wszystkim z tym, że obszary zurbanizowane są niejednorodne pod względem siedliskowym, co jest związane z różnorodnymi uwarunkowaniami antropogenicznymi. Należy w tym miejscu nadmienić, że opisywane w niniejszym artykule zjawiska przyrodnicze występują z różnym natężeniem, w zależności od stopnia antropizacji. Ze względu na znaczący udział przestrzenny pojawiającej się w miastach roślinności spontanicznej istnieje możliwość wykorzystania jej w kształtowaniu środowiska przyrodniczego na terenach zurbanizowanych.

Niniejszy artykuł powstał na bazie opublikowanego w 2008 r. artykułu pt. Miasto jako specyficzne środowisko życia roślinności (Nauka Przyroda Technologie, 2008, 2, 4, s. 1-10). Stanowi on rozwinięcie pierwotnego tekstu o zagadnienie naturyzacji roślinności na terenach zurbanizowanych, inne skutki niewłaściwego funkcjonowania szaty roślinnej w środowisku miejskim oraz o kwestie możliwości wykorzystania roślinności spontanicznej w miastach.

\section{Piśmiennictwo}

Angold P.G., Sadler J.P., Hill M.O., Pullin A., Rushton S., Austin K., Small E., Wood B., Wadsworth R., Sanderson R., Thompson K., 2006, Biodiversity in urban habitat patches, Science of The Total Environment, 360, s. 196-204.

Atlas ekofizjograficzny miasta stołecznego Warszawy, 2018, Biuro Architektury i Planowania Przestrzennego, Warszawa.

Biernacka E., Madany R., 1990, Rozprzestrzenianie się zanieczyszczeń metalicznych w aglomeracji warszawskiej w przekroju południkowym, [w:] H. Zimny (red.), Funkcjonowanie układów ekologicznych w warunkach zurbanizowanych, Wydawnictwo SGGW, Warszawa, s. 87-94.

Blume H.P., 1998, Böden, [w:] H. Sukopp, R. Wittig, W. Fischer (red.), Stadtökologie, Stuttgart, Jena, Lubeck, Ulm, s. 168-185.

Błażejczyk K., Kuchcik M., Milewski P., Dudek W., Kręcisz B., Szmyd J., Błażejczyk A., Degórska B., Pałczyński C., 2014, Miejska wyspa ciepła w Warszawie, IGiPZ PAN, Wydawnictwo Akademickie SEDNO, Warszawa.

Bornkamm R., 2007, Spontaneous development of woody vegetation on differing soils, Flora, 202, s. $695-704$.

Borowski J., Latocha P., 2006, Dobór drzew i krzewów do warunków przyulicznych Warszawy i miast centralnej Polski, Rocznik Dendrologiczny, 54, s. 83-93.

Böhm R., 1998, Urban bias in temperature series - a case study for the city of Vienna, Climatic Change, 28, s. 113-198. 
Breuste J.H., 2004, Decision making planning and design for the conservation of indigenous vegetation within urban development, Landscape and Urban Planning, 68, s. 439-452.

Chojnacki J., 1991, Zróżnicowanie przestrzenne roślinności Warszawy, Wydawnictwo UW, Warszawa.

Czarnowska K., Gworek B., 1991, Stan zanieczyszczenia cynkiem, ołowiem i miedziq gleb Warszawy, Roczniki Gleboznawcze, 42, 1/2, s. 51-59.

Czarnowska K., Konecka-Betley K., 1984, Wpływ zanieczyszczeń atmosfery na akumulację metali ciężkich w glebach i roślinności na terenie Warszawy, [w:] H. Szczepanowska (red.), Wpływ zieleni na kształtowanie środowiska przyrodniczego, PWN, Warszawa, s. 151-162.

Czerwiński Z., Pracz J., 1990, Gleby i kierunki ich transformacji w warunkach presji urbanistycznej, [w:] H. Zimny (red.), Funkcjonowanie układów ekologicznych w warunkach zurbanizowanych, Wydawnictwo SGGW, Warszawa, 58, s. 41-69.

Devigneaud P., Denayer-De Smet S., 1977, L'ecosysteme urban bruxellois, [w:] P. Duvigneaud, P. Kestemont (red.), Productivite biologique en Belgique, SCOPE, Travaux de la Section Belge du Programme Biologique International Gemblox, s. 581-599.

Faliński J.B., 2001, Interpretacja współczesnych przemian roślinności na podstawach teorii synantropizacji i teorii syndynamiki, Prace Geograficzne, 179, s. 31-52.

Generalna Dyrekcja Ochrony Środowiska, 2014, Ogrodnictwo wobec roślin inwazyjnych obcego pochodzenia. Kodeks dobrych praktyk, Warszawa.

Goddard M., Dougill A.., Benton T., 2009, Scaling up from gardens: Biodiversity conservation in urban environments, Trends in Ecology \& Evolution, 25, 2, s. 90-98.

Guo G., Wu Z., Xiao R., Chen Y., Liu X., Zhang X., 2015, Impacts of urban biophysical composition on land surface temperature in urban heat island clusters, Landscape and Urban Planning, 135, s. $1-10$.

GUS, 2017, Obszary tematyczne. Ludność. Struktura Ludności, stat.gov.pl (25.11.2017).

Harris J.A., 1991, The biology of soils in urban areas, [w:] P. Bullock, P. Gregory (red.), Soils in the urban environment, Blackwell, Oxford, s. 139-152.

Horbert M., 1978, Klimatische und lufthygenische Aspekte der Stadt, Natur und Heimat, 38, s. 34-49. Jackowiak B., 1996, Chorogical-ecological model of the spread of Puccinellia distans in Central Europe, Fragmenta Floristica and Geobotanica Polonica, 41, s. 551-561.

Jackowiak B., 1998, Struktura przestrzenna flory dużego miasta, Bogucki Wydawnictwo Naukowe, Poznań.

Janecki J., 1983, Człowiek a roślinność synantropijna na przykładzie Warszawy, Wydawnictwo SGGW-AR, Warszawa.

Jankowska K., 1971, Net primary production during three year succession on an unmowed meadow of the Arrhenatheretum elatioris plant association, Bulletin of the Polish Academy of Sciences, Biologie, 19, 12, s. 789-794.

Kowarik I., 1990, Some response of flora and vegetation to urbanization in Central Europe [w:] H. Sukopp, S. Hejny, I. Kowarik (red.), Urban ecology. Plants and plant communities in urban environments, SPB, Academic Publishing, Den Haag, s. 45-74.

Kozieł M., 2010, Ochrona walorów przyrodniczo-krajobrazowych na pograniczu polsko-białoruskim na przykładzie Puszczy Białowieskiej, Problemy Ekologii Krajobrazu, 26, s. 271-284.

Kozłowska A., 2001, Mapa roślinności Warszawy w skali 1:10 000. Założenia teoretyczne, metoda wykonania i zastosowanie, Przegląd Geograficzny, 180, s. 107-119.

Kozłowska-Szczęsna T., Krawczyk B., Błażejczyk K., 2001, Charakterystyczne cechy klimatu Warszawy, Przegląd Geograficzny, 180, s. 39-56. 
Krawczyk B., Węcławowicz G. (red.), 2001, Badania środowiska fizycznogeograficznego aglomeracji warszawskiej, Przegląd Geograficzny, 180, Warszawa.

Kühn I., Klotz S., 2006, Urbanization and homogenization - comparing the floras of urban and rural areas in Germany, Biological Conservation, 127, s. 292-300.

Kühn N., 2006, Spontaneous vegetation as the basis for innovative planting design in urban aeras, Journal of Landscape Architecture, 3, s. 46-53.

Mc Kinney M., 2002, Urbanization, biodiversity and conservation, Bioscience, 52, s. 883-890.

McKinney M., Kowarik J., Kendal D. (red.), 2018, Wild urban ecosystems: Challenges and opportunities for urban development, Urban Forestry \& Urban Greening, 29.

Landolt E., 1991, Die Entstehung einer mitteleuropäischen Stadtflora am Beispiel der Stadt Zürich, Annali di Botanica, 49, s. 109-147.

Landsberg E., 1981, The urban climate, International Geophysics Series, 28, Academic Press, New York.

Li X., Zhou W., Ouyang W., 2013, Relationship between land surface temperature and spatial pattern of greenspace: What are the effects of spatial resolution?, Landscape und Urban Planning, 114, s. 1-8.

Lundholm J.T., Marlin A., 2006, Habitat origins and microhabitat preferences of urban plant species, Urban Ecosystem, 9, 1, s. 39-159.

Maksymiuk G., 2008, Rozwój terenów wypoczynkowych Warszawy w latach 1989-2006, SGGW, Warszawa (maszynopis rozprawy doktorskiej).

Manta D., Angelone M., Bellanca A., Neri R., Sprovieri M., 2003, Heavy metals in urban soils: A case study from the city of Palermo (Sicily), Italy, Science of the Total Environment, 300, s. 229-243.

Mędrzycki M., 1990, Fenologia drzew w warunkach miejskich, [w:] H. Zimny (red.), Funkcjonowanie układów ekologicznych w warunkach zurbanizowanych, Wydawnictwo SGGW, Warszawa, s. 140-153.

Nagendra H., Gopal D., 2011, Tree diversity, distribution, history and change in urban parks: Studies in Bangalore, India, Urban Ecosystems, 14, s. 211-223.

Oke T.R., 1982, The energetic basis of the urban heat island, Journal of the Royal Meteorological Society, 108, s. 1-24.

Opracowanie ekofizjograficzne do studium uwarunkowań kierunków zagospodarowania przestrzennego m. st. Warszawy, 2006, Miejska Pracownia Planowania Przestrzennego i Strategii Rozwoju, Warszawa.

Pasternak D., 1980, Analysis of methods for estimating primary production of meadows, Polish Ecological Studies, 6, 3, s. 509-543.

Rebele F., 1994, Urban ecology and special features of urban ecosystems, Global Ecology and Biogeography, 4, s. 173-187.

Rink D., Arndt T., Banse J., 2018, Public perception of spontaneous vegetation on brownfields in urban areas. Results from surveys in Dresden and Leipzig, Urban Forestry \& Urban Greening, 29, s. 384-392.

Rusakov A., Novikov V., 2003, Biological activity in modern and buried soils of the historical Centre of St. Petersburg, Microbiology, 72, 1, s. 103-109.

Sachse U., Starfinger U., Kowarik I., 1990, Synanthropic woody species in the urban area of Berlin (West), [w:] H. Sukopp, S. Hejny, I. Kowarik (red.), Urban ecology. Plants and plant communities in urban environments, SPB Academic Publishing, The Hague, s. 233-243.

Sikorska D., Sikorski P., Richard H.J., 2016, High biodiversity of green infrastructure does not contribute to recreational ecosystem services, Sustainability, 8, s. 334-347. 
Sikorski P., 2013, Wpływ naturyzacji parku miejskiego na różnorodność florystycznq runa i trawników parkowych, Wydawnictwo Wieś Jutra, Warszawa.

Sikorski P., Wysocki C., Wierzba M., Sikorska D., 2015, Możliwości i potrzeby kształtowania różnorodności szaty roślinnej osiedli mieszkaniowych, [w:] B. Szulczewska (red.), Osiedle mieszkaniowe w strukturze przyrodniczej miasta, Wydawnictwo SGGW, Warszawa, s. 93-109.

Stańczyk T., 2015, Gospodarowanie wodami opadowymi na osiedlach, [w:] B. Szulczewska (red.), Osiedle mieszkaniowe w strukturze przyrodniczej miasta, Wydawnictwo SGGW, Warszawa, s. 79-92.

Stawicka J., Wysocki C., Wieczorek J., 2006, The influence of soli salinity on floral variability of street lawns in Warsaw, Annals of Warsaw University of Life Sciences - SGGW, Horticulture and Landscape Architecture, 27, s. 73-81.

Sudnik-Wójcikowska B., 1998, Czasowe i przestrzenne aspekty procesu synantropizacji flory, Wydawnictwo UW, Warszawa.

Sudra P., 2015, Usługi ekosystemowe na tle wybranych koncepcji ekologii miasta, Człowiek i Środowisko, 39, 1, s. 61-73.

Sukopp H., 1983, Ökologische Charakteristik von Grosstädten, Grundriss Stadtplanung, Akademie für Raumforschung und Landesplanung, Hannover, s. 51-82

Sukopp H., Wurzel A., 1995, Klima- und Florenveränderungen in Stadtgebieten, Landschaftökologie, 4, s. 103-130.

Sukopp H., 2004, Human-caused impact on preserved vegetation, Landscape and Urban Planning, 68, s. 347-355.

Szczepanowska B. (red.), 1984, Wpływ zieleni na kształtowanie środowiska miejskiego, PWN, Warszawa.

Szulczewska B., 2002, Teoria ekosystemu w koncepcjach rozwoju miast, Rozprawy Naukowe i Monografie, Wydawnictwo SGGW, Warszawa.

Szulczewska B., Giedych R., Solarek K., 2015, Problemy stosowania wskaźnika terenów biologicznie czynnych na tle wyników badań - podsumowanie, [w:] B. Szulczewska (red.), Osiedle mieszkaniowe w strukturze przyrodniczej miasta, Wydawnictwo SGGW, Warszawa, s. 141-148.

Szumacher I., 2011, Functions of urban greenspace and ecosystem services, Miscellanea Geographica, 15, s. 123-129.

Tokarska-Guzik B., Dajdok Z., Zając M., Zając A., Urbisz A., Danielewicz W., Hołdyński C., 2014, Rośliny obcego pochodzenia w Polsce ze szczególnym uwzględnieniem gatunków inwazyjnych, Generalna Dyrekcja Ochrony Środowiska, Warszawa.

Trzaskowska E., 2011, Zbiorowiska synantropijne: niedoceniony potencjał współczesnych miast, Acta Scientiarum Polonorum. Administratio Locorum, 10, 3, s. 55-66.

Trzaskowska E., 2013, Wykorzystanie roślin i zbiorowisk synantropijnych na terenach zieleni Lublina, KUL, Lublin.

Trzaskowska E., Miszczuk A., 2017, Zieleń jako element podnoszqcy atrakcyjność i jakość przestrzeni publicznych, Acta Scientarum Polonorum. Administratio Locorum, 1, s. 49-58.

Weber-Siwirska M., Czekalski M., 2004, Odnawianie się generatywne drzew i krzewów na terenie Wrocławia, Rocznik Dendrologiczny, 55, s. 97-112.

Weng Q., Lu D., Schubring J., 2004, Estimation of land surface temperature - vegetation abundance relationship for urban heat is/and studies, Remote Sensing of Environment, 89, s. 467-483.

White M.P., Alcock I., Wheeler B.W., Depledge M.H., 2013, Would you be happier living in a greener urban area?, Psychological Science, 24, 6, s. 920-928. 
Wittig R., Kunming X., 1993, Analyse der Artenzusammmensetzung des Hordeetum murini in sieben Europäischen Großstädten entlang eines West-Ost-Transektes, Phytocoenologia, 23, s. 319-324.

Wysocki C., 1994, Studia nad funkcjonowaniem trawników na obszarach zurbanizowanych, Rozprawy Naukowe i Monografie, Wydawnictwo SGGW, Warszawa.

Wysocki C., 2008, Miasto jako specyficzne środowisko życia roślinności, Nauka Przyroda Technologie, 2, 4, s. 1-10.

Wysocki C., Stawicka J., 2000, Ocena zmian florystycznych runi trawników miejskich, Łąkarstwo w Polsce, 3, s. 169-176.

Wysocki C., Zimny H., 1983, Biomass production of urban lawns, Polish Ecological Studies, 9, 1-2, s. 207-223.

Zachariasz A., 2012, Parki przyszłości - o różnych koncepcjach kształtowania terenów zieleni w miastach, Czasopismo Techniczne, 1, s. 455-462.

Zerbe S., Choi I., Kowarik I., 2004, Characteristic and habitats of non-native plant species in the city of Chonju, southern Korea, Ecological Research, 19, s. 91-98.

Zimny H. (red.), 1983, Physiocenosis within Warsaw agglomeration, Polish Ecological Studies, 9, $1-2$.

Zimny H., 1976, Miasto jako układ ekologiczny, Wiadomości Ekologiczne, 22, s. 345-353.

Zimny H., 2005, Ekologia miasta, ARW, Warszawa.

Żukowska-Wieszczek D., Zimny H., Wysocki C., 1984, Rozkład błonnika w glebach a produktywność biomasy trawników na terenie Warszawy, [w:] H. Szczepanowska (red.), Wpływ zieleni na ksztattowanie środowiska przyrodniczego, PWN, Warszawa, s. 181-192.

\section{Summary}

The problem of the proper functioning of plant cover in urbanised conditions is extremely important in the context of improving the quality of life of city-dwellers. In connection with this, an urgent task is appropriate shaping of green areas to provide better living conditions in cities. Currently, a new trend in the development of recreational areas entails the use and maintenance of undeveloped land, post-industrial areas, etc., as areas which can be adapted to the recreational function to a greater or lesser extent.

The natural environment of cities is obviously much-transformed by human beings. This is particularly true for vegetation, despite this being one of the most important elements of a city's spatial structure. This leaves efforts to recognise threats impacting on the growth and development of vegetation as extremely justified.

This study has sought to present the functioning of vegetation both deliberately shaped by people, and occurring spontaneously, in the specific conditions of the urbanised environment.

The ecological point of view is that a city can be treated as a specific natural environment, which is transformed as natural factors become limited, in favour of technical elements. In line with this idea, components of the natural environment like vegetation, animals and soils, and then water, atmospheric air and climatic conditions could prove easy to change. The specific conditions of the urban environment presented above exert their impact on the functioning of vegetation. This is reflected in the reduced productivity of vegetation, shorter growing season, and synanthropisation of vegetation, all seen to characterise the environment of cities. Productivity is an important measure of the 
functioning of natural areas. Research was conducted on the various kinds of grassy sward accounting for about $60 \%$ of the greenspace in cities. Urban grasslands of the most basic type were shown to have levels of productivity less than half as high as the lawns present in parks. Lawns are likewise characterised by significantly lower productivity than similar vegetation systems occurring outside the city, e.g. mesic meadows of the Arrhenatheretum elatioris association. Shorter growing seasons have a disruptive effect upon the vegetation present in urbanised conditions, and especially upon street greenery. Moreover, the season both starts and ends earlier. Trees in parks are generally characterised by a longer growing season than those along streets. This is particularly evident when results for Fraxinus excelsior and Tilia cordata are considered, with differences in the lengths of the growing seasons for these trees reaching several dozen days. The longest growing season noted is that of Tilia tomentosa, while the shortest characterises Acer pseudoplatanus. Urban greenspace includes synanthropic vegetation alongside the collection of species sown or planted in a conscious manner. Synanthropic plant cover reflects the process of ecological succession most often ongoing in undeveloped areas. Synanthropic vegetation is dominant in habitats subject to the impact of human activities. However, in syntaxonomic terms, the spontaneous vegetation arising in urban areas proves very diverse, and the floristic composition entailing perennial species present in synanthropic communities is especially important in shaping the greenspace present in cities. Plant species typically represent vegetation of the communities Artemisietea vulgaris, Artemisio-Tanacetetum, Echio-Melitotetum and Lolio-Polygonetum arenastri. Plants typical for Koelerio-Corynephoretea canescentis grow in poor and acidophilous habitats, while vegetation similar to the xerothermic grasslands of class Festuco-Brometea occur in thermophilous and slightly alkaline areas. In floristic terms, a greater share of synanthropic species in the vascular-plant flora is to be observed in cities, as opposed to non-urbanised areas. The vegetation of urban areas even has alien species prevalent over native plants, probably in line with necessary adaptation to specific conditions in urban habitats. For example, the appearance of a thermophilous flora related to Mediterranean vegetation is to be observed in Polish cities. This presumably reflects the heat-island conditions characteristic of the urban environment. On the other hand, native species typifying forests, xerothermic grasslands, forest edges, water and peatland communities continue to disappear from the urban landscape. Vegetation of the city is not only represented by greenspace in the typical sense of the term, with an important role being played by vegetation arising spontaneously within the urban ecological system. Such spontaneous vegetation includes both natural and synanthropic plants, occurring in places still subject to human impacts even if partially abandoned in the short term.

In recent times, the idea of the vegetation in cities (including of spontaneous origin) being subject to naturalisation has gained strong promotion as urban greenspace is being planned. There are many examples of spontaneous vegetation forming an aspect of the planning of greenspace in Europe, the United States, and Poland also. However, differing views expressed by inhabitants act to limit the use - and level of acceptance - of urban areas' spontaneous vegetation. Nevertheless, thanks to progressing ecological education, areas with synanthropic vegetation of a "more natural" character are proving increasingly acceptable to the public. 